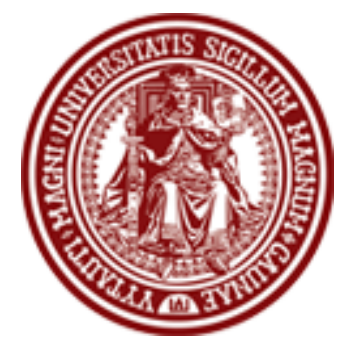

DE DE GRUYTER OPEN

\section{BALTIC JOURNAL OF LAW \& POLITICS}

A Journal of Vytautas Magnus University

VOLUME 10, NUMBER 1 (2017)

ISSN 2029-0454

\title{
NON-TERRITORIAL SPACES OF BELARUSIAN POLITICAL NOMADISM
}

\section{Viktorija Rusinaité}

Ph.D. Candidate

Vytautas Magnus University, Faculty of Political Science and Diplomacy (Lithuania)

\section{Contact information}

Address: V. Putvinskio st. 23-604, LT-44243, Kaunas, Lithuania

Phone: +370 37206709

E-mail address: v.rusinaite@pmdf.vdu.It

Received: October 3, 2016; reviews: 2; accepted: June 15, 2017.

\section{ABSTRACT}

In Belarus the state systematically hinders the development of civil society. NGOs have difficulties registering, functioning and sustaining their organisations. Some individuals related to the civil sector are persecuted, fined, imprisoned. Therefore a number of NGOs are registered abroad and civil society activists move with them to continue their work on Belarusian issues. In this article we aim to define people who left Belarus in order to work for Belarus as Belarusian Political Nomads, using the notion of transnational subjectivity to explore their migration strategies.

The article is based on 15 semi-structured interviews held in London (UK) and Vilnius (LT). Interviews were analysed using the concepts of transnational subjectivities and political nomadism, and combining elements from a critical events narrative analysis approach.

People who left Belarus to work for Belarus are Belarusian Political Nomads, because they create new democratic development visions for Belarus. Their individual political motivation can stem from the critical events that were registered in this research as turning 
points. Informants, individual conditions, histories and life experiences influence the outcomes of these events in terms of interpretation and induced motivation to engage in civil society activities.

Belarusian Political Nomads form their migration strategies on the basis of their transnational subjectivities, which can be characterised by temporal and symbolic relations to the receiving country, and long-term intensive dissociative relations to the sending countries' political regime, as well as a strong relationship to the new visions of Belarus.

\section{KEYWORDS}

Political nomadism, transnational subjectivities, Belarus, civil society, Belarusian civil society, Ranciere, Deleuze 


\section{INTRODUCTION}

The Belarusian state increasingly burdens the conditions to create and sustain independent civil society organisations.

Governmental power in Belarus is centralised, the party system is not functioning ${ }^{1}$, and the presidential institution controls all branches of the government, including the judiciary and legislature ${ }^{2}$. Presidential rule in Belarus is authoritarian; it disregards democratic institutions and procedures ${ }^{3}$. Although in Belarus laws contain democratic provisions, presidential decrees have repeatedly overpowered and undermined them. ${ }^{4}$ The presidential institution has concentrated and centralised governmental and military power and views NGOs as political agents ${ }^{5}$.

In Belarus the classical partnership model where NGOs act as a liaison between the society and the public authorities does not function. The state systematically obstructs the civil society sector; it liquidates organisations which do not follow government's lead, and initiates criminal cases against leaders of human rights organisations. It creates legal obstacles for NGOs to register and act, and persecutes civil society activists.

To create an association in Belarus founders have to fulfil the requirement to have a legal address in the rented or owned business premises, as laid out in the 2005 Law on Housing. ${ }^{6}$ There have to be at least 50 founders to register a national

\footnotetext{
${ }^{1}$ Stephen White and Ian McAllister, "Patterns of Political Culture"; in: Stephen White, Elena Korosteleva, and John Lowenhardt, eds., Postcommnist Belarus (United States of America: Rowman \& Littlefield Publishers, 2005); Elena Korosteleva, "The Emergence of a Party System"; in: Stephen White, Elena Korosteleva, and John Lowenhardt, eds., Postcommnist Belarus (United States of America: Rowman \& Littlefield Publishers, 2005).

2 Vitali Silitski, "Contagion Deterred: Preemtive Authoritarianism in the Former Soviet Union (the Case of Belarus)"; in: Valerie Bunce, Michael McFaul, and Kathryn Stoner-Weiss, eds., Democracy and Authoritarianism in the Postcommunist World, $1^{\text {st }}$ ed. (Cambridge University Press, 2009).

3 Ronald J. Hill, "Post-Soviet Belarus: In Search of Direction"; in: Stephen White, Elena Korosteleva, and John Lowenhardt, eds., Postcommnist Belarus (United States of America: Rowman \& Littlefield Publishers, 2005).

4 Venice Commission, Council of Europe, "Opinion on the compatibility with universal human rights standards of article 193-1 of the criminal code on the rights of non-registered associations of the Republic of Belarus adopted by the Venice Commission at its 88th Plenary Session (Venice, 14-15 October 2011)" (2011) // http://www.venice.coe.int/webforms/documents/?pdf=CDL-AD(2011)036-e.

5 Anastasiya Matchanka, "Substitution of Civil Society in Belarus: Government-Organised NonGovernmental Organisations," Journal of Belarusian Studies 7, No. 2 (2014); Ihar Rasolka, "Politisation of Civil Society in an Apolitical Society: Paternalism, Deconsolidation and Action Strategies of Social Agents"; in: Civil Society in Belarus 2000-2015. Collection of Texts (Warsaw: East European Democratic Centre, 2015) //

http://issuu.com/eedc_warsaw/docs/final_civil_society_in_belarus_inte_5d21802f640249/3?e=5048453 /14443508.

6 Amnesty International, "Belarus: What Is Not Permitted Is Prohibited: Silencing Civil Society in Belarus" (May 15, 2013) //

https://www.amnesty.org/download/Documents/12000/eur490062013en.pdf.; Civil Society, Dialogue for Progress, Belarus Civil Society Organisations in Cross-Sectoral Dialogue: Experts Survey (Minsk: Civil Society. Dialogue for Progress, 2014) //

http://www.csdialogue.eu/news/belarus-civil-society-organisations-cross-sectoral-dialogue-expertssurvey.
} 
association; 10 founders can register a local association. ${ }^{7}$ Even when this requirement is fulfilled, the state denies registration on an arbitrary basis. ${ }^{8}$ Despite numerous attempts to provide registration documents to the registering agency, some organisations are repeatedly denied registration, and the motivation for refusal is minor mistakes in these documents, including spelling errors. ${ }^{9}$

The criminal liability is foreseen for not following the legal procedure to obtain and use foreign grants ${ }^{10}$ Foreign funding has to be registered with the state and it is forbidden for NGOs to hold accounts in foreign banks. ${ }^{11}$

In 1999, following the presidential decree, all public organisations were unregistered, including political parties, NGOs and trade unions. ${ }^{12}$ Some of the organisations never acquired registration again and continued to work unregistered in Belarus. A number of prominent human rights organisations were dissolved, including HRC "Viasna", NGO Legal Assistance to the Population, Civil Initiatives Resource Centre and many others. Although some dissolution cases were based on the usage of unregistered foreign aid and tax evasion, others were dissolved for minor inconsistencies, for example, usage of the word "organisation" instead of "association" in the official papers (case of $P C$ "Varuta"), violations of regulations concerning printing equipment (case of The Centre for Youth Initiatives "Kontur")13. Acting on behalf of an unregistered organisation is punishable by fines, arrest up to 6 months and imprisonment up to 2 years for failing to comply with this law. ${ }^{14}$

Additionally, the government establishes and/or supports organisations mirroring the authentic NGO sector, filling the civil society niche and helping to fake democratic political life in Belarus ${ }^{15}$. To be a part of a civil society organisation in Belarus is a complicated, exhausting, expensive and dangerous job. That is why a lot of organisations, especially in the fields of human rights, democratic education, LGBT and others, are registering their offices abroad, but continue working on Belarusian issues. A number of active Belarusians are moving to other countries to

\footnotetext{
7 United Nations, Environmental Performance Reviews: Belarus ECE/CEP/129 (United Nations Publications, 2005).

${ }^{8}$ Venice Commission, Council of Europe, supra note 4.

9 Human Rights Watch, "World Report 2015: Belarus" (January 29, 2015) //

https://www.hrw.org/world-report/2015/country-chapters/belarus.

10 Amnesty International, supra note 6.; ICNL, "Belarus - NGO Law Monitor - Research Center - ICNL" (2015) //

http://www.icnl.org/research/monitor/belarus.html.

11 Tatsiana Chulitskaya, "Belarusian NGOs and the West: A Way Forward," Bell BelarusInfo Letter (2013).

12 Maxim Padbiarozkin, "The Development of NGOs in Belarus," The BEARR Trust Newsletter No. 58, (2012) // http://www.bearr.org/pdfs/bearrnews_no58_WEB.pdf; Elena Tonkacheva, "Non-Profit Organisations in the Republic of Belarus. Legislative Regulation and Issues of Law Application," Belarus the third sector (Wschodnioeuropejskie Centrum Demokratyczne, 2001) // http://bzh.kamunikat.org/download.php?item=1972-16.pdf\&pubref=1972; Amnesty International, supra note 6.

13 ICNL, supra note 10.

14 Ibid.

15 Anastasiya Matchanka, supra note 5.
} 
work as personnel in these organisations and lead their civil society related activities from abroad.

This article aims to define people who left Belarus in order to work for Belarus as Belarusian Political Nomads, using the notion of transnational subjectivity to explore their migration strategies. The notions of political nomadism and transnational subjectivities are derived from twentieth-century continental poststructuralist philosophy. Continental post-structuralist philosophy offers readings into reality that value complexity and multiplicity. This perspective is helpful in qualitative research based on thick descriptions and in-depth interview approaches, because it enables strategies of understanding and explanation using non-binary multidimensional thinking and deconstruction. Scholars invent terminology to grasp certain parts of reality, and in some cases they also aim to renegotiate and reclaim the meanings of already existing notions, which have lost their function. The selected terms - political nomadism and transnational subjectivity - are beneficial because, first, they are able to tackle individual dimensions of how people relate to the state order and their migration experience. Second, these notions are able to comprehend the processual properties of reality. Third, they enable to recognise a distinction between the political and other forms of reality.

Transnational subjectivities in this article will be analysed following Myria's Georgiou's ideas ${ }^{16}$, as individual ways of relating to transnational experiences of migration and living in between, identifying the aspects which informants repeatedly mentioned in their accounts of migration.

Political nomadism will be analysed along the lines proposed by Gilles Deleuze, Felix Guattari and Jacques Ranciere, and their proposed notions of nomadism, the political and the police. Using Jacques Ranciere's account of the political we will show that the political defines a process, during which a new configuration of reality is brought to light and the senses. Recognising that there is more to political migration than exile, refugee or "voting with the feet," and along with the signposts provided by the analysis of the political, we will explore the notion of the nomad, which has both spatial (moving in space) and political (shifting the provided order) dimensions.

\footnotetext{
16 Myria Georgiou, "Between Strategic Nostalgia and Banal Nomadism: Explorations of Transnational Subjectivity among Arab Audiences," International Journal of Cultural Studies 16, No. 1 (2012) // doi:10.1177/1367877912441429.
} 


\section{GLOBAL CIVIL SOCIETY AND TRANSNATIONAL SUBJECTIVITIES}

Transnational means transcending the borders of the nation state. ${ }^{17}$ In the pre 'nation-state' world transnational connections and communities were a common state of affairs in trade, religion and ethnical diasporas. ${ }^{18}$ Although the national seems to live off the founding myths, integral representative narration of national identity and the seemingly absolute structures of the state, its functioning order is temporal when faced with the transnational economic structures ${ }^{19}$, deterritorialized migratory or diasporical post-national communities ${ }^{20}$, or supranational religious authorities.

Transnationalism is sometimes used as a term to define an "escape mechanism or a mode of coping with global capitalist transformations", and as an adjective defining way of action of underrepresented groups, which form transnational communities on the basis of their inequality experience and social injustice. ${ }^{21}$ The world wide web, online tools (including so called internet of things) and other transnational infrastructures can help to facilitate their self-organisation and communicate their ideas.

Many researchers have already analysed the transnational dimension pertaining civil societies all over the world. Their analysis includes transnational civil society organisations, or transnational knowledge sharing networks and protests against transnational actors ${ }^{22}$ and also the transnational nature of the post-soviet transformation, where transnational actors such as transnational NGOs were involved in the transformation of states and the emergence of the new ones. ${ }^{23}$ Between the years 1990 and 1999 the United States invested 10,278 million U.S. dollars in order to foster democracy in Eurasia, and 3,640 million dollars in order to foster democracy in Central and Eastern Europe. ${ }^{24}$ Among other things, those funds were used to finance civil society organisations in the region. Global civil society

\footnotetext{
17 [No author named], "Definition of Transnational," Merriam-Webster Online Dictionary // http://www.merriam-webster.com/dictionary/transnational.

18 Paul Kennedy and Victor Roudometof, "Transnationalism in a Global Age"; in: Paul Kennedy and Victor Roudometof, eds., Communities Across Borders: New Immigrants and Transnational Culture (Taylor \& Francis, 2007).

19 Saskia Sassen, "Spatialities and Temporalities of the Global: Elements for a Theorization," Public Culture 12, No. 1 (2000) // doi:10.1215/08992363-12-1-215.

20 Arjun Appadurai, Modernity at Large. Cultural Dimensions of Globalization, Vol. 1, Public Worlds (Minneapolis-London: University of Minnesota Press, 1996); Nikos Papastergiadis, The Turbulence of Migration: Globalization, Deterritorialization and Hybridity (Wiley, 2013).

21 Paul Kennedy and Victor Roudometof, supra note 18: 4.

22 Arjun Appadurai, supra note 20; Donatella Della Porta and Sidney G. Tarrow, Transnational Protest and Global Activism (Rowman \& Littlefield, 2005); Ann M. Florini and P. J. Simmons, "What the World Needs Now"; in: Ann Florini, ed., The Third Force: The Rise of Transnational Civil Society (Carnegie Endowment for International Peace, 2000); Paul Kennedy and Victor Roudometof, supra note 18.

23 Sarah E. Mendelson and John K. Glenn, "Introduction: Transnational Networks and NGOs in Postcommunist Societies"; in: Sarah E. Mendelson and John K. Glenn, eds., The Power and Limits of NGOs (Columbia University Press, 2002); Mary Kaldor, "The Idea of Global Civil Society," International Affairs 79, No. 3 (2014).

${ }^{24}$ Sarah E. Mendelson and John K. Glenn, supra note 23.
} 
became one of the social and political players in the region, where the post-cold war ideological atmosphere undergirds newly arisen political tensions between the U.S., Russia, and the EU.

For civil society organisations a transnational way of action may be a viable way to influence local governments, and when the channels between the government and civil society are blocked, activists might turn to their transnational allies to exert pressure on the governments. ${ }^{25}$ This is one of the reasons why authoritarian and totalitarian states persecute transnational civil society organisations or even criminalise involvement with them.

Developments of global transnational capitalism, new production technologies, communication and mobility impact states, organisations and the lives of individuals-these developments set the background for transnational social relationships and transnational subjectivities: two separate modes of transnational coherence, where the first is concerned with transnational relationships and networks of humans, machines, and organisations and other with mode of personal membership and belonging to the transnational space. ${ }^{26}$ Although the transnational dimension might persist in organisational and social activities, individual subjectivity might be strongly bound to the specific territory or, on the other hand, dissociated and dispersed in space. For example, in her analysis of Arab audiences in Europe, Myria Georgiou defines transnational subjectivity as referring "to people's personal experiences of travel, (re-)settlement and their networked world of meaningful relations, as juxtaposed with their perceptions of systems of political and mediated representations that support or limit opportunities for participation in socio-economic, political and cultural spaces they occupy". She then presents us with two modes of migrant transnational subjectivity. (1) Strategic nostalgia, where current identification depends on the memory of collective past, experiences of loss and grief over the people and places left behind during migratory experience and uprooting, which results in diasporisation. (2) Banal nomadism concerned with subjectivities of the people who feel unease having to locate themselves in the singular cultural and political space, and their root themselves in many spaces. ${ }^{27}$

This research is concerned with individual motivations and strategies for a transnational way of life; therefore it analyses the transnational subjectivities of people who left Belarus to work for Belarus.

\footnotetext{
25 Margaret E. Keck and Kathryn Sikkink, "Transnational Advocacy Networks in International and Regional Politics," International Social Science Journal 51, No. 159 (1999) // doi:10.1111/1468-2451.00179.

26 Janine Dahinden, "Are We All Transnationals Now? Network Transnationalism and Transnational Subjectivity: The Differing Impacts of Globalization on the Inhabitants of a Small Swiss City," Ethnic and Racial Studies 32, No. 8 (2009) // doi:10.1080/01419870802506534.

27 Myria Georgiou, supra note 16, 24.
} 


\section{POLITICAL NOMADS}

The political is generally understood as defining processes, actors and phenomena related to governing institutions, government, administration ${ }^{28}$ and therefore implying expert knowledge. This dominant notion of the political is instrumental and unfit to consider noninstitutional politics and individual dimensions, which are essential for this research.

The term "political" derives from polis (Greek) - a city and polités (Gr.) citizen. ${ }^{29}$ Etymologically, the political on the macro level is related to the urban cohabitation order and on the individual plane - being a citizen and beging a part of an allegiance in the city. So in this sense the political works on all planes, from macro to micro, from ideologies, governmentality to individual agency. French philosopher Jacques Ranciere pushes the understanding of the political further by proposing two different concepts: the police ${ }^{30}$ and the political for in-depth understanding of the cohabitation orders and drives, which govern them.

For him the police consists of the implicit and unspoken order of laws and things, which govern the disposition defining those who have and have not a share. ${ }^{31}$ Having a share means to have equal standing and say in the matters of the societal arrangements. For example, in representative democracies every adult can vote through the election mechanism; however, in the practice of some states wealthy lobbying groups or religious authorities have more influence over the passed legislation than the electorate. So in these conditions for underrepresented groups to have an equal standing and say in the societal arrangements is an extraordinary event. For Ranciere the absolute fittingness of groups to their actions and functions, the places where these actions should be exercised, ways of being and most importantly the absence of void (identification of something that is missing in the social arrangement), signifies the police order ${ }^{32}$. The police is the "tangible configuration" of ways of doing, ways of being. It is the distribution of roles and places. It is an implicit law "that defines a party's share or a lack of it."33 In other words, the police order requires for underrepresented groups to stay underrepresented, and for those in power to stay in power.

\footnotetext{
${ }^{28}$ [No author named], "Definition of Political," Merriam-Webster Online Dictionary // http://www.merriam-webster.com/dictionary/political.

29 Terry Hoad, "Definition of Political"; in: The Concise Oxford Dictionary of English Etymology (Paw Prints, 2008).

${ }^{30}$ Here and further the police and the political used in italic will refer to these terms in Rancierian sense.

31 Jacques Rancière, Dis-Agreement. Politics and Philosophy (Minneapolis-London: University of Minnesota Press, 1999); Jacques Rancière and Davide Panagia and Rachel Bowlby. "Ten Theses on Politics," Theory \& Event 5, no. 3 (2001) // doi:10.1353/tae.2001.0028.

32 Ibid.

33 Jacques Rancière, Dis-Agreement. Politics and Philosophy, supra note 31, 29.
} 
The police accounts for all modes of subordination, including physical and ideological, on structural, organisational and individual domains. For the police order, there is no difference between the ruling and the other classes, because the police order applies to all and functions as a general law, commanding "Move Along! There is nothing to see!" 34 Once seeing that democracy is not about participation in decision making, and elections are forged in Belarus, move along blindly and accept the election results. Upon seeing that the state does not want the authentic civil society to function in Belarus, move along - find yourself another occupation. Since this general rule of moving along constitutes the configuration of the space and the ways of doing and speaking, within the police order there is no void to be filled with different ways of doing and speaking. Within the police order it is impossible to reconfigure the space. According to the police order the societal arrangement is already there being implemented and becoming daily, the space is already configured and the shares and roles are distributed. The role of the police is to further implement this order and guard the existing arrangement.

For Jacques Ranciere "the essence of the political is dissensus. Dissensus is not a confrontation between interests or opinions. It is the demonstration (manifestation) of the gap in the sensible itself. $<. .>$ Now, the specificity of political dissensus is that its partners are no more constituted than is the object or stage of discussion itself." 35 The parties that had no part become visible. What was unsayable, becomes heard. It is through the political process that those who had no part, no voice, no place, make themselves seen, heard and accountable ${ }^{36}$. Participants in the political dissensus sketch a new political reality, in which the argument put forward holds true, and the conflict just confirms the existing arrangement. For the purposes of this article, the Rancierian understanding of the political and the police will help to shape the notion of political nomadism.

Etymologically derived from the French word cite, the city, the citizen is a dweller of the city. For the specific kind of Belarusian citizens who in order to continue their citizen activities had to leave Belarus, dwelling has a rather different meaning. Deprived of their physical cité they must search for a new base, in order to constantly sustain, develop and perform the idea of their cité - a different democratic Belarus. Estranged from the existing nation-state and at the same time seeking for this specific nation state image, they become what Eugene Holland calls nomad citizens.

\footnotetext{
34 Jacques Rancière, Dissensus. On Politics and Aesthetics, edited by Steven Corcoran (London and New York: Continuum, 2010), 37.

${ }^{35}$ Ibid., 38, 39.

36 Jacques Rancière, Dis-Agreement. Politics and Philosophy, supra note 31.
} 
Nomad, from Greek nomas, nomad means roaming about. For Deleuze and Guattari, the concept of nomadism goes against hierarchies and centralisation. A nomad is essentially something deterritorialised. For example, a migrant differs from a nomad, because a migrant reterritorialises arriving and settling in the new territory, but the nomad is always following deterritorialising flows. ${ }^{37}$ It is not that nomad does not have a territory. The migrant is sedentary; when they migrate, they leave space behind and relocate in a new one. The nomad lives in the "smooth space", just as Bedouins inhabit the desert, a nomad inhabits the space, not the location $^{38}$. In the plateau of the police, governing bodies, state, parties, opposition - all are territorialised to their structures, hierarchies, roles and functions. So spontaneous political activism, which reconfigures itself through the different planes and functions is nomadic; from the book club to the protest to the social movement, which disperses into other protests, and so on.

Following their ideas, Holland conceptualised the notion of nomad citizen, rejecting the central power of the state and its inherent hierarchies. This concept aims to demonopolise the notion of citizenship from the state and conceptualise alternative modes of belonging and allegiance. Nomad citizens are citizens not because they were born within the State, automatically acquiring its citizenship and then performed it under the rule of State law, but because the performance of their civil activities and acting within their citizenship vision they re-create the State ${ }^{39}$. Nomad citizenship relies on bottom-up, self-organised and spontaneous initiatives. ${ }^{40}$

There are a lot of similarities in Ranciere's account of the political and Deleuze's and Guattari's reterritorializing nomadic flow. Territorialisation and sedentary flow, on the other hand, works in similar ways as the Rancierian police order. Territorialisation structures put things into order and hierarchy, supply roles and functions, and communicate routes. If what once was unaccounted for and had no place is accepted through the political process, it is integrated in the societal order. Like the vote for women was introduced to the political process, not only supplying women equal rights to vote as citizens, but also effecting the general societal arrangement of who a citizen is and therefore what party politics (or should we say police?) is, how it works and who it is concerned with. Reterritorialization is sedentary. Nomadic flows which deterritorialise are rather different: "<..> even though the nomadic trajectory may follow trails or customary routes, it does not

37 Gilles Deleuze and Félix Guattari, A Thousand Plateus. Capitalism and Schizophrenia (London: University of Minnesota Press, 2005).

38 Ibid.

39 Eugene W. Holland, Nomad Citizenship: Free-Market Communism and the Slow-Motion General Strike (Minneapolis: University of Minnesota Press, 2011).

${ }^{40}$ Ibid.; Gilles Deleuze and Félix Guattari, Anti-Oedipus: Capitalism and Schizophrenia (Penguin Group (USA) Incorporated, 2009). 
fulfil the function of the sedentary road, which is to parcel out a closed space to people, assigning each person a share and regulating the communication between shares." 41

Both the nomadic and political are concepts prone to mobility. Ranciere defines politics as mobile in the sea, and the police grounded on the shore. The nomad belongs in smooth spaces, such as the desert, where the nomad roams which because of its fluidity and absence of direct location can be related to the sea. ${ }^{42}$ Similarly, as the new worlds brought by redistribution of the sensible and what used to be the political become the police, so it too gets integrated into the order of things, nomadic flows hit the line of flight to detteritorialise and then to reterritorialise again.

Deleuze and Guattari sees sedentary similarly to Ranciere's account of the police, which "<..> defines the allocations of ways of doing, ways of being, and ways of saying, and sees that those bodies are assigned by name to a particular place and task;"43 both sedentary and the police distributes people within space and space between people, and defines their communication. The sedentary works in a closed space, the police works with a complete system, a finite void-less order.

Holland tailored the concept of nomad citizenship for activist groups, roots initiatives and their lifestyles in Western societies. For Western nomad citizens rejecting the inherent hierarchies may mean disillusionment with electoral politics, organised communities and civil action. In Belarus the political participation is strained, opposition parties and their leaders are persecuted, civil society organisations dissolved and their leaders incarcerated. At the same time the system uses the elements of the democratic state: it holds elections (where one candidate wins since 1995), the constitution includes democratic provisions (but presidential decrees override them), there is a party system (but opposition parties and their leaders are persecuted), and a civil sector (a significant part of which is created and sustained by the state). To be a good citizen for a system which pretends to be democratic means to act according to the police order - to follow the unwritten rules of self-censorship and limited action. So in this system, where state power pertains to almost every aspect of life, genuine civil action automatically rejects the state and repudiates its legitimacy. Being persecuted or feeling in danger, some of Belarusian nomad citizens are forced to take the state-civil antagonism further and physically migrate in order to start or continue their civil activities.

\footnotetext{
41 Gilles Deleuze and Félix Guattari, A Thousand Plateus. Capitalism and Schizophrenia (London: University Of Minnesota Press, 2005), p. 380.

42 Jacques Rancière, On the Shores of Politics (Verso, 1995); Mark Purcell, "Rancière and Revolution," Space and Polity 18, No. 2 (2014) // doi:10.1080/13562576.2014.911591.

43 Jacques Rancière, Dis-Agreement. Politics and Philosophy, supra note 31, 29.
} 
The nomadic dimension of the Belarusian Political Nomad therefore unfolds on two planes:

- The political nomadism plane, which accounts for rejecting the existing state order and governmental procedures.

- The physical migration plane, which accounts for physical relocation, movement of bodies and organisations.

\section{THE METHOD FOR EXPLORING MIGRATION STRATEGIES}

In order to grasp the complex live-in realities of Belarusian Political Nomads and migration strategies they employ, the selected method should allow for disclosing their experiences and revealing the associated events, people, overlapping historical and geographical contexts. Researchers can study these experiences through representations - i.e. the stories and the ways these stories are told. ${ }^{44}$ These stories here are considered narrative forms.

In this research we use terminology based on post-structuralist ideas that seek to account for multiplicities and differences that Belarusian Political Nomads express when defining who they are, why they migrate and what the relationship is between their migration motives and the reality which they experienced back in Belarus. Generally, post-structuralists recognise the world as processual and complex beyond full cognition, and post-structuralism in general aims to open-up structuralist thought based on hierarchies and binaries for a critique favouring complexity. This corresponds to the general postmodernist atmosphere not only in the cultural, but also in the scientific field. Postmodernism "refines our sensitivity to differences and reinforces our ability to tolerate the incommensurable." 45 So not only postmodernism exposes us to vast differences, but it also supplies us with tools to recognise and productively use the knowledge about these differences. One of the important post-modernist postulates is that representational systems and their meanings are always in process and negotiated. Therefore this research regards the interview method as co-production at least between the interviewer and the interviewee, ${ }^{46}$ and it also recognises that multiple contexts and discourses in various ways influences the outcomes of this co-production, including processes of interviewing, texts produced, and interpretations provided.

We recognise that:

\footnotetext{
44 Yvonna S. Lincoln and Norman K. Denzin, Turning Points in Qualitative Research: Tying Knots in a Handkerchief (Rowman Altamira, 2003).

45 Jean François Lyotard, The Postmodern Condition: A Report on Knowledge (University of Minnesota Press, 1986).

${ }^{46}$ Steinar Kvale, InterViews: An Introduction to Qualitative Research Interviewing, $1^{\text {st }}$ ed. (Thousand Oaks, Calif: SAGE Publications, Inc, 1996).
} 
- The method is performative. ${ }^{47}$ It is not a neutral tool or faceless readymade technology, but rather has processual qualities in the way it is made and used. The method is changing when in use, depending on who uses it, when, where, for what purpose and with whom.

- The interview method is a coproduction between the researcher and the interviewee. ${ }^{48}$ Where they come from, their understandings, educations, contexts and situations, ways of speaking influence the process.

- The method "helps to produce realities" 49 - all methods are directly involved in production of the research results. What is discovered in the research process is discovered in collaboration with the method.

- The ways of reporting the results and providing analysis influences the ways in which the produced results are understood.

- Arrangements that a certain method produces have political implications. ${ }^{50}$ It may help to sustain the current reality, to conceal it, to question it or to expose it. By doing so, it may help to sustain the status quo, or to move towards changing it.

Having this in mind, we will employ the concepts o transnational subjectivity and political nomadism to analyse the data collected during the series of 15 qualitative semi-structured interviews with activists, former long term residents in Belarus, who work on Belarusian civil society issues from abroad. ${ }^{51}$

The interviews were held betwen 2012 and 2015 in Vilnius and London. The 4 pilot interviews were conducted in London to refine the questionnaire, and 11 interviews were conducted in Vilnius. We chose Vilnius because it is the main destination for NGOs to relocate or to have a second office. It is 190 kilometres away from the Belarusian capital Minsk. Comparing to other nearby locations it has the most favourable conditions for NGOs, including organisations specialising on technical support in the registration process. We chose London as an alternative location, where Belarusian activists work for transnational NGOs, which specialise on Belarus as one of their work tracks.

In this research accessing prospective informants was problematic. There is no public record on migrants from Belarus who have relocated to Lithuania in order to continue civil society work in Belarus, and no record exists accounting for citizens of Belarus who move between Lithuania and Belarus for activities related to civil society. In the course of the pilot research, where more than half of the inquires did

47 John Law, After Method: Mess in Social Science Research (Routledge, 2004), 143.

48 Steinar Kvale, supra note 46.

49 John Law, supra note 47, 143.

50 Ibid.

51 Interviews are the primary data of work-in-progress data collection for doctoral thesis, under preparation in Vytautas Magnus University, supervised by prof. Gintautas Mažeikis. 
not generate any response, the trust issues concerning intelligence and surveillance became evident. Therefore the trust gained through recommendations, meeting eye to eye, thorough presentation of the research became very important. This all led to non-probability, or so-called "snowball" sampling, where informants recommend each other. The interviews were held in Russian and English.

The semi-structured interviews were based on a questionnaire which focused on three topics - identity, political life and migration experience, and the interrelations between those topics. The participants were encouraged to share their personal stories of migration. The collected data was coded and analysed using NVivo 11.2.2 software package for Mac, coding the themes, dimensions and narrative structures, with the emphasis on the turning points in the participant's personal history.

Turning points derive from the event based narrative analysis approach, which aims to register the events that have the most essential impact on the story flow. In literary narrative analysis, turning points are crises in the story. In narrative analysis approach the stories told by the informants are treated similarly to literary stories, in order to understand the structure behind them and its meaning in the wider context. Some scholars working with event based narrative analysis focus on the Most Reportable Events - ones that have the greatest impact on the storyteller and the audience. MREs capture the change in the "complexity, meaning and emotion" of the narrated story. ${ }^{52}$ Others research critical events revealing "a change of understanding or worldview by the storyteller", which has implications (sometimes traumatic) for professional and/or personal histories of the storyteller $^{53}$. It is impossible to predict critical events in the future, and only the storyteller can identify this event, since it changes the experience and perception of the storyteller herself. ${ }^{54}$ In this research we will register the turning points in the political or social events which changed participant perceptions or decisions in life. Among them we will seek to identify the events, which involved the storytellers' highest degree of agency. We will then analyse these events with an eye to the backdrop of Jacques Ranciere's concept of the political. ${ }^{55}$ In these turning points we will look for:

- newly identified parties in dissensus;

- the gap between the understandings of those two parties;

52 Jessica Ouyang and Kathleen McKeown, "Modelling Reportable Events as Turning Points in Narrative": 2156; in: 2015 Conference on Empirical Methods in Natural Language Processing (Lisbon, Portugal: 2015 Association for Computational Linguistics, 2015).

53 Leonard Webster and Patricie Mertova, Using Narrative Inquiry as a Research Method: An Introduction to Using Critical Event Narrative Analysis in Research on Learning Teaching, $1^{\text {st }}$ ed. (London, New York: Routledge, 2007).

54 Ibid.

55 Jacques Rancière, supra note 34. 
- a high degrees of agency (in order to make heard what was previously unsayable);

- their production in terms of doable and sayable, which was either invisible or non-existent before this event.

No identifying information about the participants will be provided and the gender neutral pronoun singular will be used in this article.

\section{TURNING POINTS IN THE BPNS' NARRATIVES}

In this section we want to show that people who have left Belarus to work for Belarus are political nomads. Belarusians who oppose the nature of the current political regime and are unable to perform their activities from Belarus, or were simply expelled from the country for their political actions, often choose Vilnius as their new base. Their citizen agency leads them to physical mobility between two or more places or relocation. Here we call them nomads not only because of their physical movement dynamics, but also because they envision new realities and new societal arrangements for Belarus.

The Belarusian Political Nomad (BPN) has an individual relation to Belarus as a country. The essence of this relation is the distinct value based idea-image of what Belarus is and what it should be and how they could contribute to this idea. It is not based on an inscription in the passport or the nationality of the parents. In fact, some of the people we talked to, who are working on the Belarusian case from abroad, are citizens of other countries. The value based relationship is evident in the BPNs professional and individual activities and self-representations. Here we call them Belarusian because of their activities, and not because of the documented nationality.

The political dimension within the concept of BPN stem from the BPNs' citizen actions focused on the political in Rancierian sense. BPNs are seeking change in the societal arrangement concerning participation is citizen affairs. BPNs are nomadic not only because they had to physically relocate, but also because they are dissatisfied with the current political status quo, and aim to deterritorialise the current arrangement and draft new territories of political belonging.

With their activities BPNs refuse to be tied to the modes of functioning prescribed for them by the Belarusian State. The authoritarian State aims to subordinate the third sector in Belarus by introducing various barriers for creating organisations and sustaining them. ${ }^{56}$ The authoritarian state views the agency of the third sector as a threat to single political line in Belarus. The actions of NGOs

56 ICNL, supra note 10. 
are politicised, because they threaten the single political line and therefore the police order in Belarus. One of the examples of subordination strategies are state led repression cycles:

We have electoral cycles. The cycle starts with the presidential elections, when most of repressions happen. Then come the parliamentary elections, which are also accompanied by repressions. Then come local elections, which are not very important. And then the repressions subdue. The repressions increase towards the next presidential elections. ${ }^{57}$

In this context Belarusian Political Nomadism becomes a migration strategy enabling the circumvention of State-created barriers and in this way lays a foundation for a new, qualitatively different relationship to the Belarusian State.

The Rancierian notion of the political is a tool to define the Belarusian Political Nomad. In this article we decided to grasp the political using the critical events approach from the narrative theory. Critical events perform the function of turning points in the informants' narratives. Once the critical event occurs, it is able to shift not only direction of the narrative, but also the informants' emotions associated with it. In their citizen and migratory history the Belarusian Political Nomads have experienced events where they refused to be assigned to the ways of doing, saying and the place by what Ranciere called the police. They refused to just move along ${ }^{58}$ and accept the predefined state order, enforced by administration or power structures. In the course of the interview programme, we asked informants to identify the political or social events which made a highest impact on their political outlook and decisions in life. Analysing the stories told during this part of the interviews we focused on these events as the turning points. In the narration of these events we were looking for identified parties, a gap between their positions, agency, and their production in terms of doing and saying.

In the following excerpt the storyteller describes their "first encounter with the regime":

After $* * * * * * * * *$ we were detained and spent several hours in the police station. It made a very huge impact on me, because even though I was always feeling that I am doing the right thing, that it's my way to be active for Belarus and Belarusian society, it was first time when I faced Belarusian government and regime. I was so angry at that moment: I'm student of law and for me the law is very important, and they were acting not according to the law. I became very angry and started to be more active and learning more legislation and all

57 Due to the informed consent agreements between the informants and the author all identifying information has been removed. This article does not provide names, aliases, names of organizations, places or times of the interviews, or any other information which may help to identify people or link statements to one another.

58 Jacques Rancière, Dis-Agreement. Politics and Philosophy, supra note 31. 
these processes. Because when you sit and do nothing, then nothing changes in the society and it's not the way I want the society to be.

Here the parties are defined through the division: we "were detained" and them "Belarusian regime and government". Along with these two sides in their narrative the informant strongly represents themselves: "I am", "for me", "I became", "I started", "I want". Between government actions and what the informant recognises as just there is a gap. It is recognised by the informant this way: "they were acting not according to the law". This gap becomes a source of changes in emotions in the participant's future actions. The detention event is associated with the changes in the informant's emotions: "I was so angry at the moment". It is significant because informant relates these emotions to the future actions: "and I started to be more active $<.$.$\rangle ". In the informant's narrative the$ detention event helped to shape the story of the past as different from what followed after the event, when participant became more active. In contrast to the past, this time the participant could not 'move along'. The informant explains: "it was first time when I faced Belarusian government and regime". We can interpret facing the regime as the moment of recognition and the moment of equality, where informant facing the regime recognises the illegal ways in which government acts not following the legal procedures. As is evident here, political events as turning points help to individualise experience. Although the storyteller recognises two parties, the impact of this event is individualised.

The turning point of the next narrative is associated with the events during the 2010 presidential election protests, during which the Belarusian government started a mass crackdown on the opposition, arresting hundreds of people, including 5 presidential candidates. Some of them were tortured, intimidated, and later sentenced. According to the opposition activists' and witnesses' reports, during the protest OMON special forces singled out the opposition leaders and beat them. In the following telling, state instigated violence switches the course of the participants' narrative and encourages them to mobilise colleagues for long term action.

First of all i was myself on the ploshcha ${ }^{59}$, secondly I saw the the dispersal from the protest from the beginning to the end of it, and third I was in the hospital when $* * * * * *$ was beaten and taken there. It really affected me. First night after the ploshcha my organisation, I gathered the team of people who had to document everything that is related to $* * * * * *$, and therefore my organisation made $* * * * * *$ interviews out of $* * * * * *$ who at all were in $* * * * * *$, and then we did the monitoring of all the $* * * * * *$ processes related to the ploshcha. This

59 "Ploshcha" means square in Belarusian. \#ploshcha was the main social network hashtag and the title for the Election Day protest in 2010, which were held in Oktyabrskaya Square. 
work took us 1,5 years. This is the most in-depth chronicle during any repression activities in Belarus. It includes the family names of people from law enforcement authorities and etc. The events of the 2010 December left a very strong impression on me. After $* * * * * *$, governmental security agency searched my flat, same agency questioned me and I decided that my personal responsibility is to document it all. I had an illusion that if I document it all, it will never happen again.

We may notice how this telling engenders the two distinct parties, one party being the special forces and the other protesters and civil society organisations. Similarly to the previous account, the grounds for this dissensus is the law and the gap is between what is considered just by those parties. The informant tells about the impact the events had on them: "It really affected me". Similarly as in the account presented earlier, the turning point influenced a shift in the informant's future: "I gathered a team of people", "the work took us 1,5 years". In this telling through their expressed emotions and identified actions the informant individualises the experience of the 2010 events to the highest degree: "I decided that my personal responsibility is to document it all." During the 2010 protests the police assigned the roles to the civil society and opposition as parties peripheral in the governance processes in Belarus and by forcing those rules they encouraged this party to 'move along.'

The two narratives presented above were the turning points which allowed informants to express their agency and political motivation for change. Although it is evident that political motivation can be instigated by the critical events, not all turning points lead into the same direction. Many participants identified similar events associated with state violence, which affected them and their decisions. Despite the similarity in the nature of these events, the individual outcomes for their participants were different. Some of them felt political motivation and it drove them to act, like in the accounts above; others were motivated but did not act; and there were those that felt lost and demotivated. Collectively certain event may be considered political following Ranciere's description. During such events the parties that were not there before are defined, there is a gap and a ground for dissensus, there is a moment of equality and new realities are envisioned and following these visions the current realities change. Despite the collective nature of the political event, this research shows that individual interpretations and experiences of these events may be radically different. 


\section{TRANSNATIONAL SUBJECTIVITIES OF BELARUSIAN POLITICAL NOMADS}

A number of informants had to leave Belarus, because for their organisation it was beneficial to lead activities from abroad. Some of the organisations have an office in Belarus, and have opened a second technical office in order to be able to receive funding from the foreign foundations. Others had difficulties registering or sustaining an organisation in Belarus; therefore they opened an office abroad. On the organisational plane many informants were involved in transnational work, reaching out not only to Belarus, but also to Eastern Partnership Countries and others. For example, some of the informants' organisations are part of transnational networks, collaborate with other organisations from Central and Eastern European countries and Caucasus, have stakeholders located in other countries, receive financing from the European and US funds, organise transnational solidarity campaigns. Such conditions contribute to the BPNs' transnational subjectivities.

In Vilnius diaspora and civil society infrastructure existed prior to the 2010 post-election protests and state led civil sector persecution, after which numerous individuals and organisations moved to Vilnius. This pre-existing infrastructure included a Belarusian secondary school, a Belarusian university, a museum and some of the NGOs that have relocated earlier. This infrastructure was strengthened since 2010 to include organisations assisting with registering Belarusian NGOs in Vilnius, with technical support provided by the US Freedom House and a number of donors. Belarusians Political Nomads who relocate to Vilnius arrive into a unique space characterised by close relationships, common languages, and similar ideological outlook. The individual accounts of finding the community, fitting in and belonging in this new location differ; however, all revolve around the existing Belarusian community and its role in the individual's life.

Below the informant tells about the close community they were placed into upon arrival to Lithuania and what effect it had on their relation to the new space:

In $* * * * * * * * * * 60$ we are placed in very closed community from Belarus and we could live without coming out of this community to get acquainted with Lithuania.

The community they speak about in their account is defined by relationship based on the country of origin - Belarus. This community is presented as separate from its context in Lithuania - a "closed," as well as socially and culturally

\footnotetext{
60 Here and further on - identifying information or other information that may lead to the recognition of
} participants was removed from the transcripts. 
resourceful place in providing the conditions to live within and not remain unacquainted with the outside.

For those who have the opportunity to go to Belarus, territorial proximity of Vilnius and Belarus may become an important factor in choosing the place of residence:

Lithuania is not that far from Minsk. So I can go there quite often, at least once a month. See family. I also have friends here now, so I feel myself now comfortable here.

A similar ideological outlook and being Belarusian seem to be the main grounds for meaningful local and long-distance social relationships and friendships:

All of my friends today are either my classmates, or coworkers, or just people who work in the field. Mostly they are Belarusians who promote the support of Belarusian culture and language, so probably they affected my perception of my identity.

From my home town I communicate with 3-4 persons that share the same values that I do.

Participants tell about themselves as part of the very specific ideological Belarusian community, sharing the same values of Belarusian culture and language, and working in the same field. These accounts also expose how personal values have a communicative nature, and how social relations help to integrate values as personal. The closely knit professional communities around the organisations in Vilnius become part of the social personal lives, providing comfort of the known and the common:

Community around $* * * * * * * * * * * *$ is mine. We sometimes disagree or argue, but we are one.

I am not sure about this assimilation or adaptation thing, because for me the best thing is that I don't actually have to fit in. I need a lot of private space. Vilnius give me a lot of that. I see a lot of people from Belarus, so I don't really feel away, because they are all around here and in $* * * * * * * * * * * *$ we always have people from Belarus and so I feel very comfortable here.

The second quote illustrates how the participant creates a narrative of themselves as different and culturally distant from the people living in Vilnius and belonging to another, i.e. Belarusian community. But differently from the Georgiou's subjectivity through strategic nostalgia, which favoured narratives of primordial and supported the discourses of ethnic otherness belonging in remote space, this type of subjectivity encountered in interviews with Belarusian Political Nomads more often communicates weak nostalgia towards the place, strong 
identification with the community and strong discontent with the governance system and police in Belarus. The latter is especially evident in their reflections about Vilnius, when comparing it to Minsk. Vilnius is seen as a place more open to their kind of difference, with a lot in common with Belarus in terms of history and atmosphere.

Here even looking in the public transport people are more open, talking. In Belarus people are more closed, but not because they are closed personalities, but because of all the pressure on all levels starting from the very low, to the very high. So people are more gloomy. They are not that smiley, they are scared, or they do not want to do something to show themselves off.

Vilnius is comfortable, it is cosmopolitan. To move here from any part of the world, I think, It is comfortable. The atmosphere is special. Vilnius is Vilnius. In daily life you can talk here in Russian, Polish, Belarusian, learn Lithuanian and it is all easy. <..> It is culturally not another planet, you can adapt here very quickly. For Belarusians Vilnius is romantic, warm, historically culturally close. Much here is related to Belarusian history, this is in fact the second, if not the first spiritual capital. Not formal, but cultural. This is the city which you regard in some sense like your own.

It is evident from both quotes that transnational subjectivity forms both in relation to Belarus and to place of residence. Vilnius in many narratives is regarded as welcoming and comfortable. It is also possible to view this location as belonging to Belarusian historical continuity. In this case, the process of migration or nomadic lifestyles might be interpreted as symbolic acts of return, enrooting into a hundreds-years old narrative in the past, and through these narratives building the new commonalities with the space, and its social and political dimensions. Nationalist ideological communities and, according to Smith's et al. ${ }^{61}$ analysis of historical accounts, Belarusophille historians fix the patrimonial motherland to 'Greater Belarus", which includes Vilna, Belastok and Smolensk ${ }^{62}$. They embrace the Lithuanian Grand Duchy as the main source of the contemporary state. This is also evident in some interviews. However, in others Lithuania and Vilnius are seen as a temporal, undemanding location. A stop, a point in time and space, where the long-term Belarusian civil society space temporarily exists:

People who came to Vilnius from civil society, they are most probably not intending to act in the traditional sense like diaspora. They act more separate, and regard their being here as temporary history and personal history. These

\footnotetext{
${ }^{61}$ Graham Smith, Vivien Law, Andrew Wilson, Annette Bohr, and Edward Allworth, Nation-Building in the Post-Soviet Borderlands: The Politics of National Identities (Cambridge (England), New York: Cambridge University Press, 1998).

62 Belarusian language city names for Vilnius, Bialystok and Smolensk.
} 
are separate personalities, and separate organisations, which have the intention to build something in Lithuania, that helps them to work in Belarus.

Because of the perceived temporal stay in Lithuania and energy invested in building something intended to foment change in territorial Belarus, BPNs we spoke to did not aim to integrate or assimilate in Lithuania. Even those who feel the close relation to the idea of the Lithuanian Grand Duchy regard it as important because it is a part of certain Belarusian national narrative continuity. For BPNs to integrate would mean excess labour, because their main aim is through continuous work with Belarusian issues to create and sustain new Belarusian realities, which maybe could bring change in contemporary territorial Belarus.

During the interview programme when speaking about the migration experience several topics kept coming up. BPNs willingly spoke about the structural, organisational and individual conditions which prompted them for nomadic lifestyle; many of the participants referred to multidimensional practical and symbolic value of Vilnius City; informants often mentioned the value based relationship between them and their migratory community. Throughout the course of interviews we revealed that BPNs form their transnational subjectivities in relation to their community and individual value based relationships with people, rather than in relation to the certain places. But places too can hold symbolic meanings and their specific characteristics such as various types of accessibility might be regarded as important. BPNs as citizens associate themselves with the vision of what and how the Belarusian State should be and dissociate both from the current Belarusian state, and the states that receive them as migrants. Migration experiences influence the BPNs' transnational subjectivities because in many instances they provide access to the close knit nomad communities. These communities and relations within them are value based. For BPNs new locations provide the basis to compare Belarusian state to other states, and through that comparison to further dissociate themselves from the State regime.

\section{CONCLUSIONS}

This article aims to define people who left Belarus in order to work for Belarus as Belarusian Political Nomads, using the notion of transnational subjectivity to explore their migration strategies. Following the theories of Jacques Ranciere on the political and the police, the notion of nomadism proposed by Gilles Deleuze and Felix Guattari, and the critical events approach focusing on the turning points in the informants narratives, we were able to identify political motivations within the 
informants narratives. Therefore we called people who left Belarus to work for Belarus: Belarusian Political Nomads.

In the case of Belarusian Political Nomads the political signifies their dedication for the new and democratic development visions for Belarus. And the notion of nomad points out both their spatial strategies of living in-between or migration, and the nomadic flow, which unlike the sedentary strategy of settling in, is directed at searching for new intellectual and political territories. The current authoritarian state serves as a point from which BPNs dissociate their visions of democratic Belarus.

During the course of 15 interviews we found out that the dissociation from the current authoritarian Belarusian State is often evident when registering critical events in the BPNs narratives. These events are very often BPNs' direct experience with the Belarusian State and its power structures. In the participants narratives these events serve as turning points, which not only shift the informants' narratives in a new direction, but also effect emotions that were associated with it. In some cases the turning points overlap with what Jacques Ranciere has called the moments of equality, where the participant is able to identify involved parties and the void, which keeps one party of being involved in the societal arrangements. In BPNs' narratives turning points are often the most salient points in which agency is demonstrated. They expose the most important events, which are often related to facing the state and its power structures. We noticed that often the experienced repressions have an adverse result and instead of demotivating BPNs, they motivate them even more to continue their citizen activities. In individual cases outcomes of these critical events are different. For example, in some narratives of these turning points induced motivation for activist work, in others prompted migration. During the course of the interviews there were also turning points, which made the informants passive. Interestingly, when the same events (like the dispersal of 2010 protests) influenced the turning points in the informants' narratives, their outcomes for different individuals were different.

Therefore we can conclude that despite that some events are very likely to become turning points in people's lives and serve as political, their outcomes in terms of interpretation and produced motivation depend more on the informants' individual conditions, histories, and life experiences than the nature of the event itself.

Analysing the interviews we found out that the transnational subjectivities of BPNs are based on their migration experiences, which form in their relation to the sending and receiving countries. Many BPNs had to re-locate or start living inbetween for professional reasons. Their relationship to the receiving location Vilnius 
can be understood as threefold: first, Vilnius is a pragmatic location - it is close, comfortable, culturally acceptable; second, it holds symbolic value as belonging to specific European-Belarusian historical continuity, sourcing contemporary Belarus from Lithuanian Grand Duchy; third receiving location is seen as temporal, where integration or assimilation is not necessary and living in Belarusian civil society and an intellectual community is preferable. Interviews revealed migration related aspects, which together with the individual complex histories form the relationship to Belarus as a sending country. Belarusian society and governance are the main objects of BPNs' activities. Differently from the nature of association with the receiving location which is short term, the relation to Belarus can be characterised as in-depth and long term. The relation to the Belarusian authoritarian state is dissociative. One of the strategies of this dissociation is migration, aimed to circumvent the state created barriers for civil society. Belarusian Political Nomads form their migration strategies on the basis of their transnational subjectivities, which can be characterised by temporal and symbolic relation(s) to the receiving country, and long-term intensive dissociative relation(s) to the sending country's political regime and strong creative relationship to the new visions of Belarus.

\section{BIBLIOGRAPHY}

1. Amnesty International. "Belarus: What Is Not Permitted Is Prohibited: Silencing Civil Society in Belarus" (May 15, 2013): 1-5 // https://www.amnesty.org/download/Documents/12000/eur490062013en.pdf.

2. Appadurai, Arjun. Modernity at Large. Cultural Dimensions of Globalization. Vol. 1. Public Worlds. Minneapolis-London: University of Minnesota Press, 1996.

3. Chulitskaya, Tatsiana. "Belarusian NGOs and the West: A Way Forward." Bell BelarusInfo Letter (2013).

4. Civil Society. Dialogue for Progress. Belarus Civil Society Organisations in Cross-Sectoral Dialogue: Experts Survey. Minsk: Civil Society, Dialogue for Progress, 2014 //

http://www.csdialogue.eu/news/belarus-civil-society-organisations-crosssectoral-dialogue-experts-survey.

5. Dahinden, Janine. "Are We All Transnationals Now? Network Transnationalism and Transnational Subjectivity: The Differing Impacts of Globalization on the Inhabitants of a Small Swiss City." Ethnic and Racial Studies 32, No. 8 (2009): 1365-1386//

doi:10.1080/01419870802506534. 
6. Deleuze, Gilles, and Félix Guattari. Anti-Oedipus: Capitalism and Schizophrenia. Penguin Group (USA) Incorporated, 2009.

7. Deleuze, Gilles, and Félix Guattari. A Thousand Plateus. Capitalism and Schizophrenia. London: University of Minnesota Press, 2005.

8. Florini, Ann, and P. J. Simmons. "What the World Needs Now?": 1-15. In: Ann Florini, ed. The Third Force: The Rise of Transnational Civil Society. Carnegie Endowment for International Peace, 2000.

9. Georgiou, Myria. "Between Strategic Nostalgia and Banal Nomadism: Explorations of Transnational Subjectivity among Arab Audiences." International Journal of Cultural Studies 16, No. 1 (2012): 23-39 // doi: $10.1177 / 1367877912441429$.

10. Hill, Ronald J. "Post-Soviet Belarus: In Search of Direction": 1-16. In: Stephen White, Elena Korosteleva, and John Löwenhardt, eds. Postcommunist Belarus. Rowman \& Littlefield Publishers, 2005.

11. Hoad, Terry, "Definition of Political": 360 In: The Concise Oxford Dictionary of English Etymology. Paw Prints, 2008.

12. Holland, Eugene W. Nomad Citizenship: Free-Market Communism and the Slow-Motion General Strike. Minneapolis: University of Minnesota Press, 2011.

13. Human Rights Watch. "World Report 2015: Belarus" (January 29, 2015) // https://www.hrw.org/world-report/2015/country-chapters/belarus.

14. ICNL. "Belarus - NGO Law Monitor - Research Center - ICNL" (2015) // http://www.icnl.org/research/monitor/belarus.html.

15. Kaldor, Mary. "The Idea of Global Civil Society." International Affairs 79, No. 3 (2014): 583-593.

16. Keck, Margaret E., and Kathryn Sikkink. "Transnational Advocacy Networks in International and Regional Politics." International Social Science Journal 51, No. 159 (1999): 89-101// doi:10.1111/1468-2451.00179.

17. Kennedy, Paul, and Victor Roudometof. "Transnationalism in a Global Age": 1-23. In: Paul Kennedy and Victor Roudometof, eds. Communities Across Borders: New Immigrants and Transnational Culture. Taylor \& Francis, 2007.

18. Korosteleva, Elena. "The Emergence of a Party System": 35-58. In: Stephen White, Elena Korosteleva, and John Löwenhardt, eds. Postcommunist Belarus. Rowman \& Littlefield Publishers, 2005.

19. Kvale, Steinar. InterViews: An Introduction to Qualitative Research Interviewing. $1^{\text {st }}$ ed. Thousand Oaks, Calif: SAGE Publications Inc., 1996.

20. Law, John. After Method: Mess in Social Science Research. Routledge, 2004. 
21. Lincoln, Yvonna S., and Norman K. Denzin. Turning Points in Qualitative Research: Tying Knots in a Handkerchief. Rowman Altamira, 2003.

22. Lyotard, Jean François. The Postmodern Condition: A Report on Knowledge. University of Minnesota Press, 1986.

23. Matchanka, Anastasiya. "Substitution of Civil Society in Belarus: GovernmentOrganised Non-Governmental Organisations." Journal of Belarusian Studies 7, No. 2 (2014): 67-94.

24. Mendelson, Sarah E., and John K. Glenn. "Introduction: Transnational Networks and NGOs in Postcommunist Societies": 1-28. In: Sarah E. Mendelson and John K. Glenn, eds. The Power and Limits of NGOs. Columbia University Press, 2002.

25. [No author named]. "Definition of Political." Merriam-Webster Online Dictionary //

http://www.merriam-webster.com/dictionary/political.

26. [No author named]. "Definition of Transnational." Merriam-Webster Online Dictionary //

http://www.merriam-webster.com/dictionary/transnational.

27. Ouyang, Jessica, and Kathleen McKeown. "Modelling Reportable Events as Turning Points in Narrative": 2149-2158. In: 2015 Conference on Empirical Methods in Natural Language Processing. Lisbon, Portugal: 2015 Association for Computational Linguistics, 2015.

28. Padbiarozkin, Maxim. "The Development of NGOs in Belarus." The BEARR Trust Newsletter No. 58 (2012): 13-14 // http://www.bearr.org/pdfs/bearrnews_no58_WEB.pdf.

29. Papastergiadis, Nikos. The Turbulence of Migration: Globalization, Deterritorialization and Hybridity. Wiley, 2013.

30. Porta, Donatella Della, and Sidney G. Tarrow. Transnational Protest and Global Activism. Rowman \& Littlefield, 2005.

31. Purcell, Mark. "Rancière and Revolution." Space and Polity 18, No. 2 (2014): $168-181 / /$ doi:10.1080/13562576.2014.911591.

32. Rancière, Jacques. Dis-Agreement. Politics and Philosophy. MinneapolisLondon: University of Minnesota Press, 1999.

33. Rancière, Jacques. Dissensus. On Politics and Aesthetics. Edited by Steven Corcoran. London and New York: Continuum, 2010.

34. Rancière, Jacques. On the Shores of Politics. Verso, 1995.

35. Rancière, Jacques, David Panagia and Rachel Bowlby. "Ten Theses on Politics." Theory \& Event 5 , No. 3 (2001) // doi:10.1353/tae.2001.0028. 
36. Rasolka, Ihar. "Politisation of Civil Society in an Apolitical Society: Paternalism, Deconsolidation and Action Strategies of Social Agents": 61-66. In: Civil Society in Belarus 2000-2015. Collection of Texts. Warsaw: East European Democratic Centre, 2015 // http://issuu.com/eedc_warsaw/docs/final_civil_society_in_belarus_inte_5d 21 $802 \mathrm{f} 640249 / 3 ? \mathrm{e}=5048453 / 14443508$.

37. Sassen, Saskia. "Spatialities and Temporalities of the Global: Elements for a Theorization." Public Culture 12, No. 1 (2000): 215-232 // doi:10.1215/08992363-12-1-215.

38. Silitski, Vitali. "Contagion Deterred: Preemtive Authoritarianism in the Former Soviet Union (the Case of Belarus)": 275-299. In: Valerie Bunce, Michael McFaul, and Kathryn Stoner-Weiss, eds. Democracy and Authoritarianism in the Postcommunist World. $1^{\text {st }}$ ed. Cambridge University Press, 2009.

39. Smith, Graham, Vivien Law, Andrew Wilson, Annette Bohr, and Edward Allworth. Nation-Building in the Post-Soviet Borderlands: The Politics of National Identities. Cambridge (England), New York: Cambridge University Press, 1998.

40. Tonkacheva, Elena. "Non-Profit Organisations in the Republic of Belarus. Legislative Regulation and Issues of Law Application": 90-99. In: Belarus the third sector. Minsk-Warsaw: Wschodnioeuropejskie Centrum Demokratyczne, 2002 //

http://bzh. kamunikat.org/download.php?item=1972-16.pdf\&pubref=1972.

41. United Nations. Environmental Performance Reviews: Belarus ECE/CEP/129. United Nations Publications, 2005.

42. Venice Commission, Council of Europe. "Opinion on the Compatibility with Universal Human Rights Standards of Article 193-1 of the Criminal Code on the Rights of Non-Registered Associations of the Republic of Belarus Adopted by the Venice Commission at Its 88th Plenary Session (Venice, 14-15 October 2011)" (2011) //

http://www.venice.coe.int/webforms/documents/?pdf=CDL-AD(2011)036-e.

43. Webster, Leonard, and Patricie Mertova. Using Narrative Inquiry as a Research Method: An Introduction to Using Critical Event Narrative Analysis in Research on Learning Teaching. $1^{\text {st }}$ ed. London, New York: Routledge, 2007.

44. White, Stephen, and Ian McAllister. "Patterns of Political Culture": 17-34. In: Stephen White, Elena Korosteleva, and John Lowenhardt, eds. Postcommnist Belarus. United States of America: Rowman \& Littlefield Publishers, 2005. 